\title{
LOCATION MATTERS! EXPLORING BROWNFIELDS REGENERATION IN A SPATIAL CONTEXT (A CASE STUDY OF THE SOUTH MORAVIAN REGION, CZECH REPUBLIC)
}

\author{
Bohumil FRANTÁL, Josef KUNC, Eva NOVÁKOVÁ, Petr KLUSÁČEK, \\ Stanislav MARTINÁT, Robert OSMAN
}

\begin{abstract}
In this paper the authors attempt to answer the question of which location and site-specific factors have a decisive influence on the successful regeneration of brownfields. Using data from the South Moravian Region (Czech Republic), we analyze the spatial and functional distribution of brownfields, and test the correlation between the development potential of municipalities and the distribution of the brownfields that have already been regenerated. We then compare the structure and characteristics of existing and regenerated brownfields to identify significant drivers and barriers in the regeneration process. The findings indicate that regenerated brownfields are more likely located in municipalities with a higher local development potential (represented by the rate of local business activities, spatial peripherality proximity to the regional centre and the main road network, and the quality of local infrastructure). It is also demonstrated that the large size of brownfields, their previous industrial use and the existence of contamination are not determinative barriers for regeneration if the brownfields are located in attractive areas and their ownership relations are not complicated.
\end{abstract}

\section{Shrnutí}

\section{Na poloze záleží! Zkoumání regenerace brownfields v prostorovém kontextu (př́klad Jihomoravského kraje, Česká republika)}

Článek se snaži odpovědět na otázku, které lokalizační a specifické faktory mají rozhodující vliv na úspěšnou regeneraci brownfields. $S$ využitím dat za Jihomoravský kraj, autoři analyzuji prostorovou a funkční distribuci brownfields, testují souvislost mezi rozvojovým potenciálem obcí a rozmístěním již regenerovaných brownfields a porovnávají strukturu a charakteristiky existujících a regenerovaných brownfields, aby identifikovali signifikantní katalyzátory a bariéry procesu regenerace. Výsledky ukazují, že regenerované brownfields se mnohem častěji nachází v obcích s vyšším rozvojovým potenciálem, který je reprezentován zejména mírou lokální podnikatelské aktivity, periférností (blizzkostí $k$ regionálními centru a napojením na hlavní silniční sít') a kvalitou lokální infrastruktury. Také se potvrdilo, že velikost brownfileds, jejich predchozí industriální využití a existence kontaminace nepředstavuji rozhodujicí bariéry, pokud se nachází v atraktivní lokalitě a nemaji komplikované vlastnické vztahy.

Key words: brownfields, development potential, success factors, spatial analysis, South Moravian Region, Czech Republic

\section{Introduction}

Brownfield has become a worldwide recognized term that refers to "any land or premises which has previously been used or developed and is not currently fully in use, although it may be partially occupied or utilized (...) may be vacant, derelict or contaminated (...) therefore not necessarily available for immediate use without intervention" (Alker et al., 2000:49). The term originated in the early 1990s (e.g. Laws, 1994; Syms, 1994; Hanley, 1995) when practitioners and researchers saw how emerging regulatory frameworks designed to protect the environment were (as a side effect) inhibiting the reuse (clean-up and redevelopment) of former industrial and commercial sites (Bartsch and Collaton, 1997). Brownfields are results of changing patterns of 
industry and development in many regions. They are largely regarded as liabilities degrading the value of the surrounding land (in the environmental, economic and social sense), it is often difficult to sell them, and municipalities are unable to revitalize them from their own resources (cf. Cabernet, 2005).

Some countries, for example USA, United Kingdom, France and West Germany, have long-term experience with the problems of brownfields, which had emerged already during the 1970sas aresult of massively declining mining, heavy industries and textiles. In comparison, in countries such as the Czech Republic, Slovakia, East Germany, Poland or Romania, brownfields appeared in large quantities just after the collapse of socialism with the centrally planned economy and return of a market economy and the following globalization trends during the last decade of the $20^{\text {th }}$ century.

Generally, the regeneration of brownfields has received increasing political credence in recent decades, since vacant agricultural or natural developable lands (or socalled "greenfields") become less available and more expensive in highly populated areas. The increasing number of various projects and research platforms being supported by the European Commission or national grant systems during the last decade is quite evident in the growing interest of policy makers in matters of brownfield regeneration (see the summary report on activities, products and tools developed by previous brownfield projects by Tölle et al., 2009).

However, redevelopment has not been as effective as expected in many regions. Potential investors are often afraid of risk and uncertainties related to brownfields regeneration and they prefer to develop projects on greenfields. Especially in the post-socialist countries, a majority of investors who were engaged in brownfields regeneration were companies with foreign capital, for which economic profit and a fast return on investment were the key factors of investment. Thus, projects of a commercial use (e.g. supermarkets or shopping malls, offices and representative business headquarters or lucrative housing developments) realized mostly in large cities, are the most obvious regeneration projects. On the contrary, in developed countries such as USA, Sweden, Netherlands, or Germany, more frequently projects (especially in cases of the regeneration of larger post-industrial complexes) are based on investments provided by both private and public funds or BY a so-called public-private partnership (Paull, 2008; Kalberer et al., 2005).
The objective of this paper is to answer the following questions: What factors have a decisive influence on the fact that just some brownfields have been successfully regenerated and are being newly used, while other ones stay derelict and vacant, or the process of their redevelopment has not been successfully completed? Why does the private sector invest in some regeneration areas and not in others, and what local and sitespecific factors influence the decisions of investors and developers? These are the key issues for central and regional authorities, regional development agencies, urban planners and other decision makers who are responsible for wider territories (cities, districts, regions) and who need to effectively distribute and direct limited available resources, time, and energy to those locations and sites where publicly (co-)financed regeneration is required (i.e. locations where market forces are considered to be weak and display low levels of market efficiency) (cf. Ball et al., 1998).

\section{Exploring brownfields as spatial phenomena: theoretical background}

Besides the temporal or historical factors affecting the formation and evolution of brownfields in different countries (e.g. the specifics of evolution and structure of brownfields in post-socialist countries), it is argued that internal geographical factors also affect the actual situation and patterns of redevelopment. Oliver et al. (2005) identified significant regional trends amongst definitions or respectively concepts of brownfields, which reflected the national policy strategies regarding land regeneration and development in Western Europe, Eastern Europe and the Scandinavian countries. These authors documented how two indicators - population density and economic competitiveness - at a country level, determine the perception of what brownfields and derived regeneration priorities are (i.e. definitions and policies) - from pure contamination problem focus to development potential gaining understanding (cf. Oliver et al., 2005).

Even the conceptual delimitation and definition of brownfields is a dynamic element and has been changed and modified in the course of time and geographical contexts (see Box 1).

Besides the problem of finding a consensus on the conceptual definition of brownfields, the existing research $^{1}$ on brownfield regeneration has mostly focused on the following thematic areas:

\footnotetext{
${ }^{1}$ This paper focuses primarily on research work in the field of social sciences; however, brownfield regeneration (especially the problems of soil decontamination and remediation of sites) also has been dealt with in the sphere of environmental management, engineering geology, soil ecology, etc.
} 
- Constructing a conceptual framework: structuring the regeneration process, identification of its particular phases, life cycles, components and actors (or stakeholders), and specification of their features and roles in the process - creation of regeneration "models" (e.g. Dixon and Doak, 2005; Pediaditi et al., 2005; Dixon, 2007; Williams and Dair, 2007);

- Exploring drivers and barriers: surveying and analyzing factors, which are significant for the success of the regeneration process; classification of these factors according to specific geographical or land-use contexts, exploring inter-group variability in perceptions and differences in the assessment of factors by specific stakeholder groups (e.g. Nijkamp et al., 2002; De Sousa, 2003; Lange and McNeil, 2004a; Alberini et al., 2005; Bacot and O’Dell, 2006; Dixon, 2007);

- Monitoring positive and negative effects and consequences: reporting about "good practices" or "bad practices", defining measures of success and sustainability of regeneration projects, assessing the economic, environmental and social impacts of projects (e.g. Lange and McNeill, 2004b; Franz et al., 2007; Wedding and Crawford-Brown, 2007; De Sousa et al., 2009; Doick et al., 2009; Hula, Bromley-Trujillo, 2010; Rall, Haase, 2011); and
- Developing classification and prioritization systems and assessment tools: establishing the quantitative criteria for valuation, classification and prioritization of brownfield sites as a part of the planning, decision-making and selection processes (e.g. Sayah, 2002; Thomas, 2002a, 2002b; Chen et al., 2009; Cheng et al., 2011; Bartke, 2011; Pizzol et al., 2011; Schädler et al., 2011; Agostini et al., 2012; Chrysochoou et al., 2012; Schädler et al., 2012).

The published works range from qualitative and more descriptive local case studies through to comparative case studies investigating more examples within specific areas (cities, regions) to a few complex metaevaluations of existing methodologies, classification systems and tools (Dasgupta and Tam, 2009; Pediaditi et al., 2010).

In terms of practical policy (i.e. spatial and land-use planning, regeneration management, place marketing, etc.), representatives of public administration and other decision makers at different hierarchical levels (state governments, regional authorities and regional development agencies, local governments, etc.) pay (or should pay) special attention to the following strategic tasks concerning brownfields:

\section{Box 1: Defining the indefinable?}

Prevailing diversity and fluidity of definitions is maybe the most noticeable characteristic of "brownfields". At the beginning, the term was associated primarily with urban regeneration (Hanley, 1995; Lederman and Librizzi, 1995) and brownfields were defined by some authorities strictly as city areas and buildings (cf. Alker et al., 2000; Oliver et al., 2005). Later, the concept exceeded urban space and covered rural areas, too. Some national or departmental authorities have been using the term very universally and flexibly (including objects of all (post-) industrial, agricultural, business, military, transport, warehouse, housing, sport, and other land uses), while others regarded brownfields exclusively as industrialized sites or their conceptualizations excluded some types of objects or land uses such as agriculture (Syms, 1994), mining (Czechinvest, 2008), landfills or gas stations (see the international comparison of definitions summarized by Kirschner, 2005; Oliver et al., 2005). Contamination of sites has been another selection criterion. While in some countries (e.g. USA, Romania, Italy), brownfields are solely regarded as polluted or contaminated lands, some countries (e.g. Czech Republic, England) regard soil or groundwater contamination as an obvious yet not conditional characteristic of brownfield sites.

A similar definitional problem exists for "successful regeneration". According to some politicians, almost any project of regeneration - especially in locations with a large concentration of brownfields - is a success. However, the success can be assessed from different perspectives (according to region, academic discipline, stakeholder group, etc.) and measured by different indicators (Wedding, CrawfordBrown, 2007, Rall, Haase, 2011). According to Doick et al. (2009), success in brownfield regeneration has been generically described as economic benefit (De Sousa, 2003) or as civil infrastructure renewal, tax-based development, economic development and neighbourhood revitalization (Amekudzi, Fomunung, 2004). Doick et al. (2009) stress the importance of applying the concept of sustainability (including economic, social and environmental criteria) into the assessment of projects. The issue of success is even more complicated by the fact that successful regeneration could be replaced (especially in the conditions of a market economy) by unsuccessful development very quickly (see e.g. Dixon, 2007; Bacot, O’Dell, 2006).

Generally, the problem of defining "regeneration" also has spatial and temporal aspects. The first one is connected with the question whether a brownfield can be regarded as (successfully) regenerated when just a part (e.g. a few buildings) of a larger site is redeveloped, while the rest stays derelict. Another dilemma occurs when a site has been newly used and produces economic profit but without previous intervention (remediation, reconstruction: for example if vacant buildings are used as provisional storage spaces or when solar panels are constructed on contaminated land). The temporal aspect is connected with the question of what length of time should lapse between the previous use and the new use of a site to become a brownfield and not just a continual development. In the sense of these previous questions, brownfields can be divided at least into five categories: (i) newly used after complete (or almost complete) regeneration, (ii) newly used without significant regeneration changes, (iii) within the stage of regeneration, (iv) prepared for a new development (after demolition, decontamination), (v) derelict. (cf. more detailed categorization applied by the Liberec Region (2012)).

The prevailing diversity of concepts and definitions does not simply result from diverging national approaches, legislatures and policies (see e.g. Jackson, Garb, 2002; NICOLE, 2011), but it goes hand in hand with the problem of comparability of available data, including official statistics, inventories and registers of existing brownfields, documentation of successful regeneration case studies, etc. 
- Inventorying - mapping, identification, analysis and registration of existing brownfields in specific territorial administrative units (regions, districts, cities). Inventories (registers, databases) could have the form of a table database (with basic descriptive data), info-sheets with more detailed information about sites and on-going regeneration stages and/ or GIS layers (maps with coded sites and additional information);

- Prioritizing - evaluation and classification of brownfields according to their redevelopment potential, environmental risk or other criteria, which assists in the allocation of limited available resources (funding, time and energy) to those brownfield sites that are assessed as the most critical, urgent or profitable to redevelop; and

- Marketing - the application of information from databases for marketing of selected (prioritized) brownfields, fundraising, searching for potential private investors or public subsidies (e.g. EU structural funds), promoting examples of successful regenerations ("best practices") to stimulate the regeneration process.

It is important to emphasize that brownfields do not exist by themselves, independently, or in a vacuum. They are placed and rooted in a certain geographical space, which is hierarchically and functionally structured and also determined by individual sociological contexts: therefore, every brownfield site can be seen as quite unique. The geographical environment and driving forces acting within it have resulted in the formation of brownfields, but at the same time the actual existence of brownfields affects the environment on the rebound.
Therefore, brownfields have to be perceived in their spatial context and we should take into account (when assessing them) not just site-specific attributes but also contextual factors acting at a higher hierarchical level (cf. Dasgupta, Tam, 2009; Chrysochoou et al., 2012). The factors affecting the evolution and potential regeneration of brownfields are summarized in Tab. 1.

It is not possible to say a priori which of the general factors, location factors or site-specific factors are the most important determinants and drivers of the regeneration process. The table represents an open system (with other macro factors - geographical, historical, political, and economic - acting on higher hierarchical levels, e.g. global economic trends, political processes and regulatory acts at the European Union level, etc.) where partial factors are related and affect each other. To identify and analyse the relative importance of each of these is a task for comprehensive and interdisciplinary research, which is limited by the availability of data and by the fact that it is impossible to objectively quantify and measure the effect of many factors (especially those "soft" factors acting on macro and meso levels).

With respect to brownfield regeneration, the location factors can be regarded as local development potential or area competitiveness, which is a result of and a complex expression of environmental conditions, economic potential and social capital (see e.g. Coombes, Raybould, 1989; Coombes et al., 1992; Wong, 1996). The factor of development potential of a locality is very relevant for the brownfields regeneration issue, from several points of view which

\begin{tabular}{|l|l|l|}
\hline Spatial level & \multicolumn{1}{|c|}{ Factors } & \multicolumn{1}{c|}{ Characterization } \\
\hline Macro level & General factors & $\begin{array}{l}\text { General factors are associated with political, economic, and social climate of countries or } \\
\text { broader regions. They include: the legislative instruments concerning national and regi- } \\
\text { onal development policies, spatial planning strategies; economic instruments including } \\
\text { grant titles, bank loan availability, subsidies, tax benefits, foreign direct investments; re- } \\
\text { generation management instruments including availability of information, databases, } \\
\text { tools, education, and political-institutional practices, etc. }\end{array}$ \\
\hline Meso level & Location factors & $\begin{array}{l}\text { Location factors are characteristics and attributes of the location (area) where a specific } \\
\text { brownfield is located. For different spatial levels it could be a municipality, district or re- } \\
\text { gion. Every particular factor (or measurable indicator) is relevant at a different spatial le- } \\
\text { vel according to data availability. They may include geographical location within a region, } \\
\text { transport links, socio-demographic structure of local population, economic potential, rates } \\
\text { of unemployment and business activities, social capital, and also "soft factors" such as lo- } \\
\text { cal political leadership, community involvement, etc. }\end{array}$ \\
\hline Micro level & Site-specific factors & $\begin{array}{l}\text { These factors are related to particular brownfield sites. They are typically represented by } \\
\text { the property size, previous use, number of buildings and structures, soil quality and ex- } \\
\text { tent of contamination, available infrastructure, ownership/property relations, actual pro- } \\
\text { perty price, expected demolition and remediation costs, etc. }\end{array}$ \\
\hline
\end{tabular}

Tab. 1: Spatial scale of success factors. Source: authors' conceptualization 
are all interrelated. They can be described in the form of the following assumptions or hypotheses that drive this research study:

- Brownfields have originated in areas with socioeconomic structures and a concentration of industries that were in some way affected by economic, demographic or social changes and transformations;

- Regenerated brownfields are more likely located in areas characterized by higher development potential (i.e. a low development potential of localities is one reason why investors are not interested in brownfields which are located there); and

- A long-term presence or a larger concentration of brownfields in certain localities or regions affect negatively their image and decrease even more their actual development potential.

In this study, we will try to verify the above-stated hypotheses by using brownfields data from the South Moravian Region in the Czech Republic.

\section{Case study: analysis of brownfields in the South Moravian Region}

\subsection{Study area}

The Czech Republic belongs to the group of countries with a very large recent appearance of brownfields which are especially associated with the long-term industrial traditions of the country. The fall of socialism in 1989 and the return of the free market economy caused the collapse of many economic activities, decline and restructuring of many sectors including agriculture (Svobodová and Věžník, 2009), coal mining (Vojvodíková, 2005), heavy industry (Klusáček, 2005), the textile industry, military spending (Hercik et al., 2011), etc. Later on, global economic trends further affected the restructuring of traditional industries. The current occurrence of many abandoned, neglected, unused areas and buildings of different types and scales (from smallsized areas of up to one hectare to "megasites" covering tens of square kilometres) is one of the results of these processes.
The Czechinvest Company (2008) implemented, within the scope of the Czech National Strategy of Brownfields Regeneration, a monitoring study (Search Study of the Localization of Brownfields, 2005-2007) which identified in total 2,355 brownfields in the country's territory. However, this number is approximately just one fourth of the real estimated state of all existing brownfields. Database representativeness is limited by the fact that different regions have used different methods and criteria for the mapping and inventorying of brownfields. Recently some regional authorities started to prepare their own up-dated databases of existing brownfields, with more complex information to assess and prioritize the sites according to their potential, promote them to attract investors and to stimulate the regeneration process.

For the purposes of our analysis we used the brownfields data of the South Moravian Region, which can be regarded as one of the most systematic and complex brownfield inventories in the Czech Republic. The South Moravian Region is located in the South East of the Czech Republic and shares a border with Austria and Slovakia (see Fig. 1). It is the fourth largest in area and third largest in the number of inhabitants among the regions in the Czech Republic. The region consists of 673 local administrative units (municipalities). The city of Brno is the geographical and administrative centre of the region and it is the second largest city in the Czech Republic (with

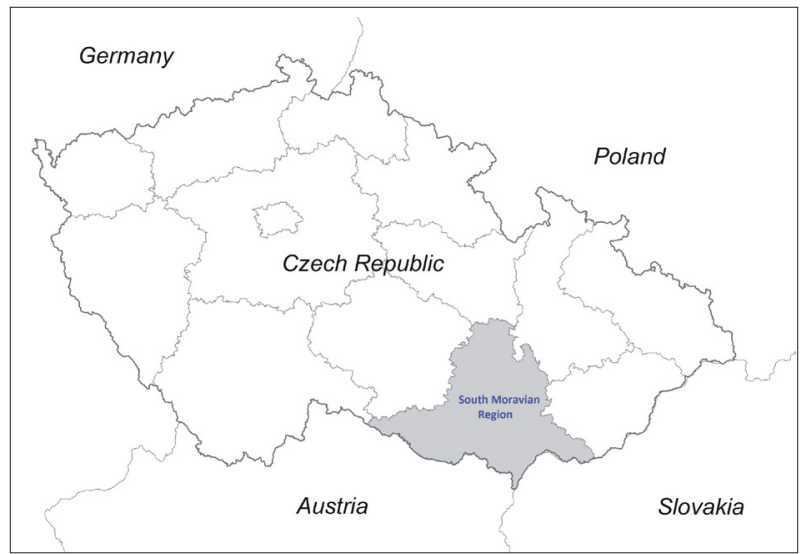

Fig. 1: Area under study

\begin{tabular}{|ll|}
\hline Total area & 719,555 ha \\
Population & $1,166,313$ (in 2011) \\
Population density & ca. 162 inhabitants/km² \\
Statutory city & Brno (population approximately 379,000 inhabitants) \\
Number of Districts (NUTS4) & 7 (Blansko, Brno, Brno-venkov, Břeclav, Hodonín, Vyškov, Znojmo) \\
Number of municipalities (NUTS5) & 673 (incl. 49 cities and 41 townships) \\
Municipalities with extended jurisdiction & 21 \\
\hline
\end{tabular}

Tab. 2: Basic characteristics of the South Moravian Region. Source: Czech Statistical Office, 2011 
ca. 379,000 residents and a greater metropolitan area with ca. 800,000 residents). Basic characteristics of the region are summarized in Table 2.

\subsection{Data sources and methods}

The objective of this paper is to analyze factors affecting successful brownfield regeneration. The analysis attempts to answer questions such as: why some brownfields have become objects of concern for developers, politicians, experts or other actors, having been selected as the most profitable or urgent to invest money, time and energy, regenerated and newlyused, while other sites have been out of attention, remaining neglected or derelict, or the process of their regeneration has not been successfully completed.

In order to answer the above questions, we apply a spatial and statistical analysis of objective data (inventories of existing and regenerated brownfields), unlike most previous studies which explored and assessed the significance of factors affecting brownfields regeneration, according to various stakeholder surveys, interviews with experts (De Sousa, 2003; Alberini et al., 2005) or case studies (reconstruction of regeneration processes) of a few specific projects (Franz et al., 2007). Moreover, while most of the previous studies focused on "soft" factors and procedural processes facilitating redevelopment (governmental support, type of funding, political leadership and collaboration, community involvement, etc.), we focus deliberately on the relevance of "hard" or more concrete spatial factors as determinants of the regeneration process.

Our analyses are based on the following data sources:

a) Regional database of existing brownfields provided by the Regional Development Agency of the South Moravian Region. This database consists of 362 brownfields located in 135 municipalities in the region (including 127 sites in Brno city). The database includes basic site characteristics such as identification code, location, site name and description, area size, original use, current use, type of ownership, contamination, available infrastructure, etc.). As concerns the size criterion, the database covers brownfield sites larger than one hectare or built-up areas larger than $500 \mathrm{~m}^{2}$ in the case of single objects;

b) Database of successfully regenerated brownfields collected by the authors from a literature retrieval of various reports about successful regenerations of brownfields (e.g. RRAJM 2010, 2011), and a survey with representatives of municipalities with extended jurisdiction (asking for examples of successful regeneration in the municipalities of their administrative district). This database includes 75 cases of regenerated brownfields located in 37 municipalities (with 35 cases in Brno city). Newly-used brownfields after complete (or almost complete) regeneration were recorded in the database (i.e. partially used sites without significant regeneration changes were excluded); and

c) Statistical data on municipalities - indicators were selected that were thought to be representative of phenomena and processes that are characteristic for the development of municipalities (including geographical, demographic and socioeconomic indicators). In this selection process, we were inspired by the previous studies of local development potential or local competitiveness (Coombes et al., 1992; Wong, 1996, 1998; Bernard, 2011). The final selection, however, was driven by the specifics of brownfields regeneration problems but also limited by the availability of statistical data at the level of municipalities in the Czech Republic.

First, we analyze the spatial distribution of existing brownfields according to their previous use, area size, current use, and property relations. Second, we assess the development potential of municipalities by applying a principal component analysis (PCA) to municipal data in order to explore the structure of relations among selected variables and to find out if they can be divided into groups with similar meanings. These groups (components) then represent new factors, which we test in relation to the spatial distribution of regenerated brownfields. Third, we apply correlation analysis to test the relations between the values of overall potential of municipalities or its components (as independent variables) and the number of regenerated brownfields in municipalities (as dependent variable) to validate our set of indicators and the assessment model. Fourth, we analyze the structure and characteristics of regenerated brownfields and compare them with the structure of existing brownfields to identify which site-specific factors are significant drivers for the regeneration process.

\subsection{Spatial distribution and structure of existing brownfields}

The spatial distribution of brownfields is uneven, i.e. there are more brownfields located in some municipal cadastres while other municipalities have no evidence of brownfields. The distribution of brownfields (see Tab. 3) reflects general national trends: the larger concentration of sites (mostly post-industrial ones) is in the larger cities (see Figures 4 and 5 on cover p. 2); the other brownfields (predominantly postagricultural) are located mostly in traditional rural micro-regions. The third most frequent types of brownfields are those previously-used objects of civic 


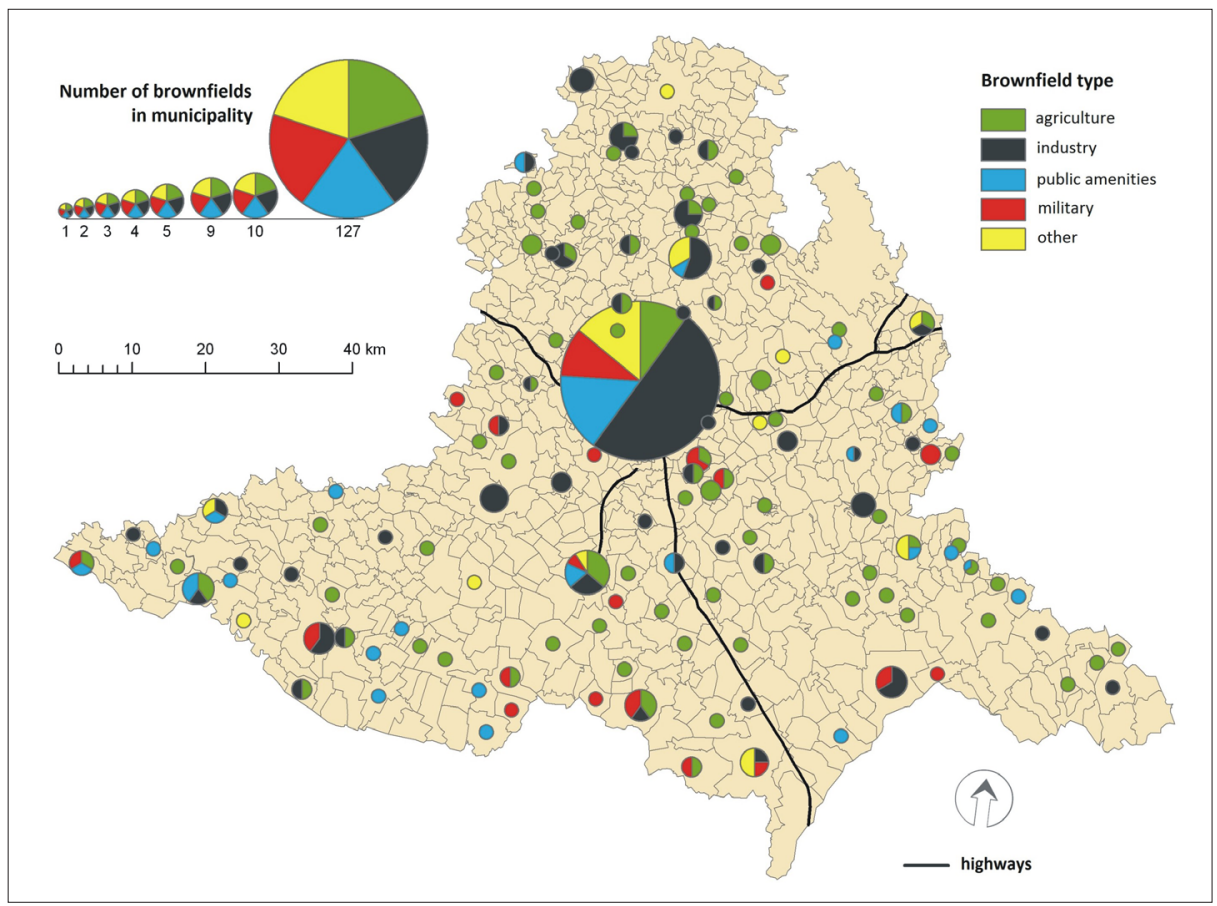

Fig. 2: Spatial distribution of existing brownfields in the South Moravian Region Source: RRAJM, authors' elaboration

\begin{tabular}{|l|c|c|c|c|c|c|}
\hline & $\begin{array}{c}\text { Total number } \\
\text { in region }\end{array}$ & $\begin{array}{c}\text { \% of total } \\
\text { in region }\end{array}$ & $\begin{array}{c}\text { \% of total } \\
\text { in Brno }\end{array}$ & $\begin{array}{c}\text { Total area (ha) } \\
\text { in region }\end{array}$ & \% of total area & $\begin{array}{c}\text { Average area } \\
\text { (ha) }\end{array}$ \\
\hline Industrial & 134 & 37.0 & 49.0 & 557 & 38.0 & 4.2 \\
\hline Agricultural & 108 & 30.0 & 11.0 & 381 & 26.0 & 3.6 \\
\hline Military & 34 & 9.5 & 9.0 & 315 & 22.0 & 9.3 \\
\hline Civic amenity & 52 & 14.0 & 16.0 & 57 & 4.0 & 1.1 \\
\hline Other & 34 & 9.5 & 14.0 & 144 & 10.0 & 4.2 \\
\hline Total & 362 & 100.0 & 100.0 & 1453 & 100.0 & 4.05 \\
\hline
\end{tabular}

Tab. 3: The structure of brownfields in the South Moravian Region according to their previous use and area size Source: RRAJM, authors' calculations

amenities (closed schools, cultural houses and hotels), which are concentrated mostly in peripheral rural areas near the southern and eastern borders of the region. A significant proportion of brownfields in the region is represented also by post-military sites and objects (barracks, hangars, etc.), which are located mostly on the southern border (previously known as the "iron curtain") with Austria and in the city of Brno and close surroundings.

As the largest city in the region, Brno has the highest concentration of brownfields. Previous industrial sites and vacant factory complexes represent nearly one half of them. There is also a higher concentration (in comparison with the rest of the region) of derelict sites of previous civic amenities, sports facilities and objects that were previously used for transport services (the most obvious type in the category of "others"). Generally (as concerns the whole region), post-military sites occupy on average the largest areas while the smallest ones are sites of abandoned civic infrastructure (schools, local cultural centres, tourist hotels). The category "other" is represented mostly by sites and buildings connected with the rail transport infrastructure, church buildings and castles.

More than one half of all brownfields (in Brno more than two thirds of brownfields) are currently partially used for some provisional productive activities (most usually some buildings are utilized as warehouses, storage spaces or premises for small-scale production and businesses). Most often, the temporarily-used spaces are parts of larger post-industrial brownfields (previous factory complexes) in cities, and buildings of former agricultural cooperatives in rural municipalities. As might be expected, brownfields without complicated property relations are more likely to be utilized. 


\subsection{Assessment of the development potential of municipalities}

A final data set comprising the 25 variables considered as indicators of local development potential was examined, from which 16 variables were used in the factor analysis (see Tab. 4). We excluded non-relational variables (i.e. variables that represent absolute values and do not account the size of spatial units/ population), subsequently variables inappropriate for the factor analysis (dichotomous variables and those with high frequencies of zero values) were excluded or transformed into new variables. We used the method of principal components analysis, with the Oblimin rotation method. The measures of the Kaiser-MeyerOlkin test of sampling adequacy $(\mathrm{KMO}=0.731)$ and Barlett's test of sphericity $(\mathrm{p}<0.001)$ confirmed the appropriateness of the selected variables for the factor analysis. The total variance explained by four extracted factors is $62 \%$. The factors were named as follows: (i) Peripherality; (ii) Demographic growth; (iii) Business activity; and (iv) Infrastructure.

At the first stage of calculating the overall development potential we recalculated the values for each of 16 ariables that were of different scales (in the ranges from $<0-3>$ to $<2-265>$ ) and transformed them into variables of similar scales. We applied a formula that allowed us to assign a dimensionless index between $0-1$ to any concrete value.

There are two possible methods of calculation, which are as follows:

a)

$$
\mathrm{I}_{x i}=\left(\mathrm{X}_{i}-\mathrm{X}_{\min }\right) /\left(\mathrm{X}_{\max }-\mathrm{X}_{\min }\right)
$$

(with the growing value of $\mathrm{X}_{i}$ indicator quality / the potential of partial indicator is increased);

b) $\quad \mathrm{I}_{x i}=\left(\mathrm{X}_{\max }-\mathrm{X}_{i}\right) /\left(\mathrm{X}_{\max }-\mathrm{X}_{\min }\right)$

(with the growing value of $\mathrm{X}_{i}$ indicator quality / the potential of partial indicator is decreased)

At the second stage we computed partial scores for all four extracted components of the development potential (accounting for the weights of respective variables resulted from the PCA), and then the overall score as a total sum of the four components. For simplicity, clarity and representation for graphic visualisation, the values for all partial components as well as the total sum index for all municipalities were converted into five categories (quintiles) according to

\begin{tabular}{|c|c|c|c|c|}
\hline & \multicolumn{4}{|c|}{ Component } \\
\hline & $\begin{array}{c}1 \\
\text { Peripherality }\end{array}$ & $\begin{array}{c}2 \\
\text { Demographic growth }\end{array}$ & $\begin{array}{c}3 \\
\text { Business activity }\end{array}$ & $\begin{array}{c}4 \\
\text { Infrastructure }\end{array}$ \\
\hline Distance from Brno city & -0.894 & & & \\
\hline Unemployment rate & -0.755 & & & \\
\hline Distance from expressway & -0.737 & & & \\
\hline Distance from MOJ & -0.559 & & & \\
\hline Housing development & & -0.858 & & \\
\hline Population growth & & -0.815 & & \\
\hline Age index & & 0.599 & & -0.473 \\
\hline Tax revenues per capita & & & 0.712 & \\
\hline Business activities & & & 0.704 & \\
\hline Education index & 0.348 & & 0.641 & \\
\hline Employment in tertiary sector & & & 0.530 & 0.341 \\
\hline State subsidies per capita & & & 0.518 & \\
\hline Population density & 0.320 & & 0.517 & \\
\hline Available communal amenities & & & & 0.795 \\
\hline Infrastructure & & & & 0.785 \\
\hline Rail connection & & & & 0.715 \\
\hline
\end{tabular}

Tab. 4: The extracted components (factors) of local development potential and factor loadings

Notes: Principal Component Analysis, rotation method Oblimin with Kaiser Normalization. Factor loadings lower than $+/-0.3$ were excluded from the Table

Note: $M O J=$ municipality of extended jurisdiction

Source: authors' calculations 
the percentage within the data definition file $(0-20$ $40-60-80-100 \%$, where $1=$ deeply below average potential; $2=$ below average potential; $3=$ average potential; $4=$ above average potential; $5=$ highly above average potential). The results are presented in the following map (see Fig. 3).

It is evident from the map that municipalities with the highest development potential are represented by district towns and smaller municipalities located in the surroundings of the regional centre and close to motorways or first class roads.

\subsection{Relation between local development potential and regeneration of brownfields}

The key question is whether the selection of our indicators and the values of overall development potential of municipalities are relevant for the process of brownfields regeneration. The statistical analysis (see Tab. 6 for the results) proved a significant correlation between the spatial distribution of regenerated brownfields and the development potential of municipalities where these brownfields are located. It is evident from the spatial distribution of regenerated brownfields (see Table 5 and Fig. 3 ) that more than $2 / 3$ of regenerated brownfields are located in municipalities of the highest development potential (categories 4 and 5) while these municipalities represent less than one fifth (17\%) of the region.

The most significant factors related to regenerated brownfields are factors of business or economic activities of the local population (which proved to be closely related to the population density) and geographical location within a region or peripherality (represented especially by proximity to regional centre and distance from main road transport axes). The factor of a municipality's infrastructure is more significant in the dataset

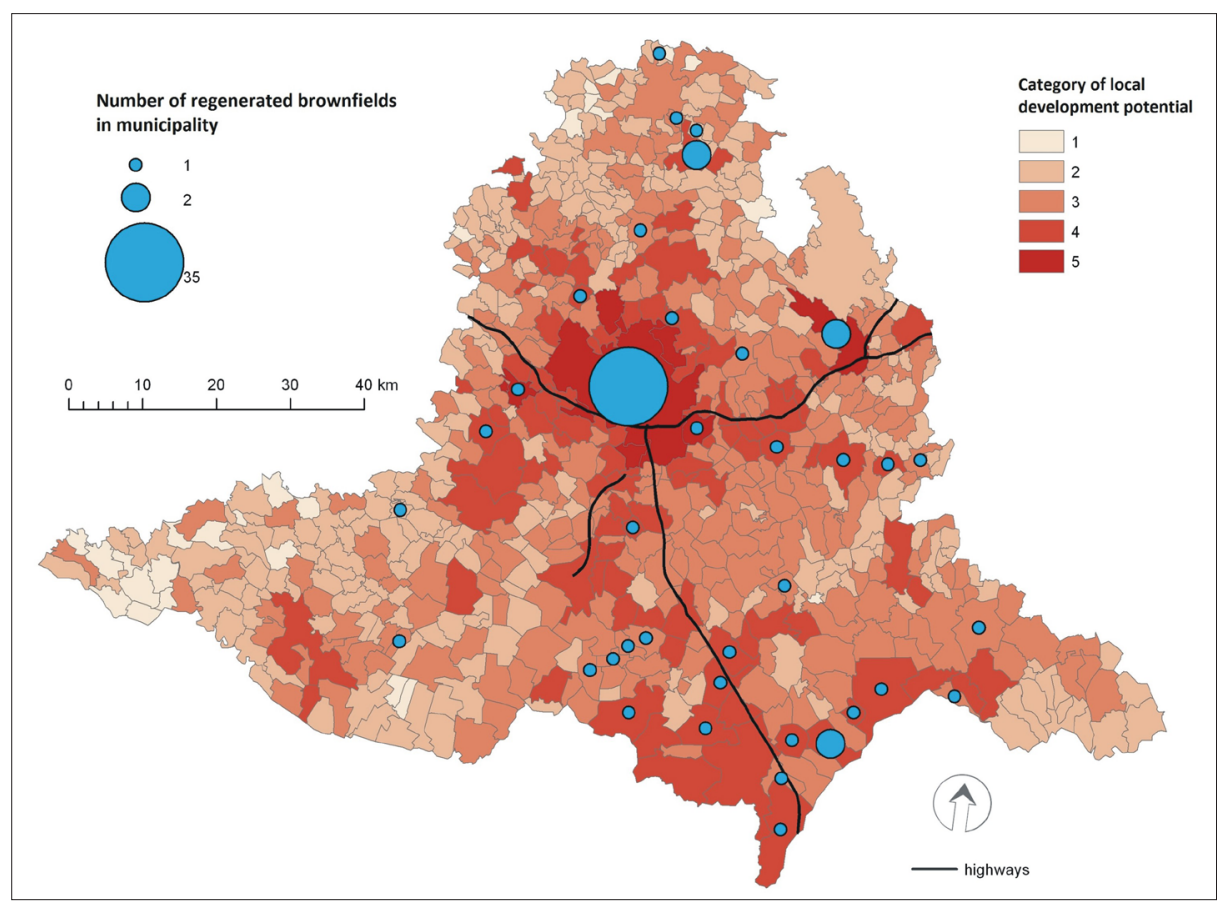

Fig. 3: Categorization of municipalities according to development potential and spatial distribution of regenerated brownfields. Source: authors' elaboration

\begin{tabular}{|c|c|c|c|}
\hline $\begin{array}{c}\text { Municipality } \\
\text { category }\end{array}$ & Share of all municipalities [\%] & $\begin{array}{c}\text { Share of all regenerated BF [\%] } \\
\text { (including Brno cases) }\end{array}$ & $\begin{array}{c}\text { Share of all regenerated BF [\%] } \\
\text { (excluding Brno cases) }\end{array}$ \\
\hline 1 & 5 & 0 & 0 \\
\hline 2 & 41 & 5 & 7 \\
\hline 3 & 37 & 20 & 45 \\
\hline 4 & 15 & 25 & 10 \\
\hline 5 & 2 & 50 & 48 \\
\hline
\end{tabular}

Tab. 5: The distribution of municipalities according to the category of development potential and the share of regenerated brownfields within each category

Source: authors' calculations 
excluding Brno city. Somewhat surprisingly, the factor of demographic growth appeared not to be significant for the regeneration of brownfields in our dataset.

\subsection{The structure of regenerated brownfields}

Table 7 presents the most frequent types of the actual use of regenerated brownfields in Brno city and the rest of the region. While in the urban areas a predominant type of new use is represented by construction of new supermarkets, shopping centres and commercial or multifunctional projects, the new use of brownfields in rural areas is represented most often by small-scale manufacturing or investment in facilities for tourism, recreation or culture (horse farms, hotels, tourist centres, museums, etc.).

More than one half of the regenerated projects (55\%) have been realized on previous industrial brownfields (mostly located in urban areas), almost a third (29\%) on agricultural brownfields (in rural areas), and a tenth $(9 \%)$ is represented by regenerated objects of previous public amenities. There are only three cases $(4 \%)$ of regenerated post-military brownfields. However, this percentage structure is very similar to the structure

\begin{tabular}{|l|c|c|}
\hline \multirow{2}{*}{\begin{tabular}{c}
\multirow{2}{*}{$\begin{array}{c}\text { Independent variables } \\
\text { (factors of local development potential) }\end{array}$} \\
\cline { 2 - 3 }
\end{tabular}} & Dataset including Brno & Dearson's correlation (r) \\
\hline Factor "Overall development potential" & $0.292^{* *}$ & $0.298^{* *}$ \\
\hline Factor "Business activities" & $0.445^{* *}$ & $0.241^{* *}$ \\
\hline Factor "Peripherality" & $-0.203^{* *}$ & $-0.222^{* *}$ \\
\hline Factor "Infrastructure" & $0.172^{*}$ & $0.232^{* *}$ \\
\hline Factor "Demographic growth" & 0.009 & -0.060 \\
\hline
\end{tabular}

Tab. 6: Correlations between regeneration of brownfields and factors of local development potential Notes: Correlation is significant at the ** 0.01 level (2-tailed) or *0.05 level (2-tailed).

Source: authors' calculations

\begin{tabular}{|l|l|}
\hline \multicolumn{1}{|c|}{ Brno (number of cases) } & \multicolumn{1}{c|}{ Rest of the Region (number of cases) } \\
\hline Shopping centres, supermarkets (10) & Manufacturing, storage, logistics (16) \\
Research and education (7) & Tourism (agro-tourism), recreation (11) \\
Manufacturing, storage, logistics (6) & Multifunctional (commercial / residential) (6) \\
Multifunctional (residential / commercial) (5) & Culture, public amenities (4) \\
Business premises, office spaces (5) & Residential (housing development) (4) \\
Sport and recreation (2) & Renewable energy (3) \\
\hline
\end{tabular}

Tab. 7: The most frequent current uses of regenerated brownfields

Source: authors' calculations

of existing brownfields (see Tab. 3). We can say that the post-industrial sites are more frequent among the regenerated brownfields (see Fig. 6 on the cover p. 2), while the military and transport brownfields are less well represented.

The average size of the regenerated brownfield is 8.5 ha (the size ranges from small objects of 0.1 ha to large 30 hectare regeneration projects). The amount of regeneration costs ranges from some ten millions of Czech crowns to hundreds of millions for the largest regeneration project (the shopping and social centre Gallery Vaňkovka in Brno).

As to contamination, somewhat less than half $(44 \%)$ of the regenerated brownfields were previously contaminated (in comparison, contamination is confirmed or expected in 54\% of the existing brownfields). Thus, we can say that the factor of contamination is not a crucial barrier for regeneration. Almost two thirds of regenerated brownfields were privately owned (at the time when regeneration started), while one third were in public ownership. An absolute majority of regenerated brownfields have had a simple ownership structure. This is a confirmation of previous studies that have emphasized that the key barrier for investment and development is a complicated (multiple) landownership related to the brownfields (see. e.g. Adams et al., 2001).

\section{Discussion and conclusions}

Our analyses have demonstrated that regenerated brownfields are more likely located in municipalities with a higher local development potential - which is represented and can be measured by the following 
specific factors and indicators: local business activities (tax revenues per capita, number of entrepreneurs, level of education of the local population and the share of people working in tertiary sector), peripherality (proximity to regional centre and district cities, proximity to main road network), and quality of the local infrastructure. According to the comparative analysis of the structure of existing and regenerated brownfields we can argue that a large size of the brownfield, its previous industrial use and the existence of contamination may not to be determinative barriers of regeneration - if the brownfield is located in an attractive area (e.g. city centre) and does not have complicated ownership relations. However, the factor of real and/or perceived contamination is more complicated and depends on an actual level of contamination (most of the existing brownfields have not gone through a complex investigation and the databases report only the status of site - with approved, expected, and/or unexpected contamination - and not the level of contamination).

Similar findings about the role of location factors have been reported from the USA by Lange and McNeil (2004a), who found that sites located near airports, close to the central city, or close to rail access are developed more quickly. Longo and Campbell (2007) analyzed revitalized brownfields in England and confirmed that sites located in more prosperous regions (London, South West, and South East) are more likely to be regenerated compared to sites located in other regions. However, they did not reveal a significant influence of population density on brownfields regeneration, nor a significant difference in the redevelopment of sites in rural versus urban areas. As concerns site-specific characteristics, a site owned by the private sector, of smaller size and suitable for housing, made it more likely to be re-used.

Studies based on surveys or interviews with stakeholders (Adair et al., 2002) showed that the primary reason why the private sector invests in some regeneration areas is the perception of achieving the target rates of return. Conversely, the principal reasons for non-investment include the negative image of a locality or neighbouring environments, the perception of bureaucratic grant regimes and the lack of capital (funding). Similarly, Coffin and Shepherd (1998) identified four key barriers to regeneration: legal liability, limited information, limited financial resources, and limited demand for the properties.

In many cases, however, even good conditions for the effectiveness and prosperity of a locality (and for brownfields regeneration) may not be utilized if there are subjective problems and barriers (weak local political involvement, a deficit of information, poor communication and cooperation (see e.g. De Sousa, 2003), i.e., if the key actors are not able or do not want to exploit the potential. On the contrary, "soft factors" such as political leadership and good cooperation of stakeholders can turn even insufficient conditions and low potential into positive results. There are many examples (so-called "best practices") reporting how human factors as an initiator of brownfields regeneration (e.g. making a good project proposal, gaining a local community support, acquiring of grant titles, etc.) have overcome locational handicaps or modified the characteristics of suitability of an area or a concrete brownfield site according to specific project purposes (see e.g. RRAJM, 2010, 2011).

Together with Adair et al. (2002), we can recapitulate that investment decisions on brownfields regeneration are a function of the availability and perceived quality of a property, occupier demand, characteristics of the local labour markets, transport links, social factors, and regulatory and planning considerations. The private sector is opportunity driven, invests in areas where it is comfortable and where returns are achievable commensurate with the risk taken - in this respect, grant regimes should be used as tools to lever investment.

Another practical problem is to differentiate between different stakeholders' (investors') concerns. Yount and Meyer (1999) emphasized (according to interviews with developers and lenders) that effective policies and programmes need to be framed within an understanding of the different needs of smaller and larger redevelopments. While market forces were equally significant inducements for both types of projects, important needs of small developers were not met: they were less likely to receive government subsidies, had greater difficulty accessing private capital, and lacked information about processes associated with remediation, while developers of large projects were more likely to benefit from public financing and were able to mobilize a network of supportive organizations to help them manage barriers to project completion.

In this respect, it is very important to study the specific local political, cultural and social structures and contexts of regeneration processes, the roles of specific actors, etc. That is a broad area for future interdisciplinary research. At the same time, it is very important to analyze (deconstruct) and present "best practices" as examples of the successful regeneration of brownfields in various geographical and land-use contexts . Finally, it is important to analyze general factors at the macro level (national legislative frameworks, policies, economies, etc.), which significantly affect factors at lower levels. 


\section{Acknowledgement}

The paper is based on research realized in the scope of the project "TIMBRE - Tailored Improvement of Brownfield Regeneration in Europe", funded from the European Community's Seventh Framework
Programme FP7/(2011-2014) under the Grant Agreement No. 265364. The authors would also like to thank the Regional Development Agency South Moravia for providing us with the database of brownfields in the South Moravian Region that has been used for the analyses.

\section{References:}

ADAIR, A. S., BERRY, J. N., McGREAL, W. S., QUINN, A. (2002): Factors Affecting the Level and Form of Private Investment in Regeneration. Report to Office of the Deputy Prime Ministr. [online] London, University of Ulster, 83 pp. Available at: http://www.rpp.ulster.ac.uk/reports/odpm_report.pdf.

ADAMS, D., DISBERRY, A., HUTCHISON, N., MUNJOMA, T. (2001): Ownership constraints to brownfield redevelopment. Environment and Planning A, Vol. 33, No. 3, p. 453-477.

AGOSTINI, P., PIZZOL, L., CRITTO, A., D'ALESSANDRO, M., ZABEO, A., MARCOMINI, A. (2012): Regional risk assessment for contaminated sites. Part 3: Spatial decision support system. Environment International, Vol. 48, No. 11, p. 121-132.

ALBERINI, A., LONGO, A., TONIN, S., TROMBETTA, F., TURVANI, M. (2005): The Role of Liability, Regulation and Economic Incentives in Brownfield Remediation and Redevelopment: Evidence from Surveys of Developers. Regional Science and Urban Economics, Vol. 35, No. 4, p. 327-351.

ALKER, S., JOY, V., ROBERTS, P., SMITH, N. (2000): The definition of brownfield. Journal of Environmental Planning and Management, Vol. 43, No. 1, p. 49-69.

AMEKUDZI, A., FOMUNUNG, I. (2004): Integrating brownfields redevelopment with transportation planning. Journal of Urban Planning and Development, Vol. 130, No. 4, p. 204-212.

BACOT, H., O’DELL, C. (2006): Establishing indicators to evaluate brownfield redevelopment. Economic Development Quarterly, Vol. 20, No. 2, p. 142-161.

BALL, M. (1998): Institutions in British Property Research: A Review. Urban Studies, Vol. 35, No. 9, p. 1501-1517.

BARTSCH, C., COLLATON, E. (1997): Brownfields: Cleaning and reusing contaminated properties. Westport, CT: Praeger, $135 \mathrm{pp}$.

BARTKE, S. (2011): Valuation of Market Uncertainties for Contaminated Land, International Journal for Strategic Property Management, Vol. 15, No. 4, p. 356-378.

BERNARD, J. (2011): Endogenní rozvojové potenciály malých venkovských obcí - obtížné hledání a měření jejich vlivu. Sociologický časopis/Czech Sociological Review, Vol. 47, No. 4, p. 745-775.

CABERNET (2005): Brownfield definition [online]. University of Nottingham. Available at: http://www.cabernet.org.uk

COFFIN, S. L., SHEPHERD, A. (1998): Barriers to Brownfield Redevelopment: Lessons Learned from Two Great Lakes States. Public Works Management Policy, Vol. 2, No. 3, p. 258-266.

COOMBES, M., RAYBOULD, S. (1989): Developing a local enterprise activity potential index. Built Environment, Vol. 14, No. 2, p. 107-117.

COOMBES, M., RAYBOULD, S., WONG, C. (1992): Developing Indicators to Assess the Potential for Urban Regeneration. London, HMSO, 67 pp.

CZECHINVEST (2008): National Strategy for Brownfields Regeneration of the Czech Republic [online] Ministry of Industry and Business. Available at: http://www.czechinvest.org/data/files/strategie-regenerace-vlada-1079.pdf.

DASGUPTA, S., TAM, E. (2009): Environmental Review: A Comprehensive Review of Existing Classification Systems of Brownfield Sites. Environmental Practice, Vol. 11, No. 4, p. 285-300.

De SOUSA, C. A. (2003): Turning brownfields into green space in the City of Toronto. Landscape and Urban Planning, Vol. 62, No. 4, p. 181-198.

De SOUSA, C. A. (2004): The greening of brownfields in American cities. Journal of Environmental Planning and Management, Vol. 47, No. 4, p. 579-600.

De SOUSA, C. A., WU, C., WESTPHAL, L. M. (2009): Assessing the Effect of Publicly Assisted Brownfield Redevelopment on Surrounding Property Values. Economic Development Quarterly, Vol. 23, No. 2, p. 95-110. 
DIXON, T. (2007): The Property Development Industry and Sustainable Urban Brownfield Regeneration in England: An Analysis of Case Studies in Thames Gateway and Greater Manchester. Urban Studies, Vol. 44, No. 12, p. 2379-2400.

DIXON, T., DOAK, J. (2005): Actors and Drivers: Who and What Makes the Brownfield Regeneration Process Go Round? [online] Proceedings of the SUBRIM conference. Sheffield. Available at: http:/www.subrim.org.uk/publications/ subrim1stconference/1030_1100actorspaper.doc.

DOICK, K. J., SELLERS, G., CASTON-BROTO, V., SILVERTHORNE, T. (2009): Understanding success in the context of brownfield greening projects: The requirement for outcome evaluation in urban greenspace success assessment. Urban Forestry \& Urban Greening, Vol. 8, No. 3, p. 163-178.

FRANZ, M., GÜLES, O., PREY, G. (2007): Place-Making and 'Green' Reuses of Brownfields in The Ruhr. Tijdschrift voor economische en sociale geografie, Vol. 99, No. 3, p. 316-328.

HANLEY, C. M. (1995): Developing Brownfields - An Overview. Journal Of Urban Technology. Vol. 2, No. 2, p. 1-8.

HERCIK, J., ŠERÝ, O., TOUŠEK, V. (2011): Post-military areas in the Czech Republic and their revitalization - examples of the towns of Hodonín and Uherské Hradiště. Acta Universitatis Palackianae Olomucensis Facultas Rerum Naturalium, Geographica, Vol. 42, No. 2, p. 107-119.

HULA, R. C., BROMLEY-TRUJILLO, R. (2010): Cleaning Up the Mess: redevelopment of Urban Brownfields. Economic Development Quarterly, Vol. 24, No. 3, p. 276-287.

CHEN, Y., HIPEL, K. W., KILGOUR, D. M., ZHU, Y. (2009): A strategic classification support system for brownfield redevelopment. Environmental Modelling and Software, Vol. 24, No. 5, p. 647-654.

CHENG, F., GEERTMAN, S., KUFFER, M., ZHAN, Q. (2011): An integrative methodology to improve brownfield redevelopment planning in Chinese cities: A case study of Futian, Shenzhen Computers, Environment and Urban Systems, Vol. 35, No. 5, p. 388-398.

CHRYSOCHOOU, M., BROWNA, K., DAHALA, G., GRANDA-CARVAJALB, K., SEGERSONB, K., GARRICKA, N., BAGTZOGLOUA, A. (2012): A GIS and indexing scheme to screen brownfields for area-wide redevelopment planning. Landscape and Urban Planning, Vol. 105, No. 3, p. 187-198.

JACKSON, J., GARB, Y. (2002): Facilitating brownfield redevelopment in Central Europe: overview and proposals. New York: Institute of Transportation and Development Policy. $17 \mathrm{pp}$.

KALBERER, A., KLEVER, S. F., LEPKE, T. [eds.] (2005): The Future lies on Brownfields. Federal Environmental Agency: [online] Available at: http://www.umweltdaten.de/publikationen/fpdf-1/3051.pdf.

KIRSCHNER, V. (2005): Klasifikace brownfields. [online] Studie k disertační práci. 46 pp. Available from: www.brownfields.cz.

KLUSÁČEK, P. (2005): Downsizing of Bituminous Coal Mining and the Restructuring of Steel Works and Heavy Machine Engineering in the Ostrava Region. Moravian Geographical Reports, Vol. 13, No. 2, p. 3-12.

LANGE, D., McNEIL ,S. (2004a): Brownfield Development: Tools for Stewardship. Journal of Urban Planning and development, Vol. 130, No. 2, p. 109-116.

LANGE, D., McNEIL, S. (2004b): Clean It and They Will Come? Defining Successful Brownfield Development. Journal of Urban Planning and Development, Vol. 130, No. 2, p. 101-108.

LAWS, E. P. (1994): Reclaiming Brownfields. Issues In Science and Technology, Vol. 11, No. 1, p. 6-7.

LEDERMAN, P. B., LIBRIZZI, W. (1995): Brownfields Remediation. Journal Of Urban Technology, Vol. 2, No. 2, p. $21-29$.

Liberecky Region (2012): Brownfieldy Libereckého kraje - zpráva o stavu revitalizace.

LONGO, A., CAMPBELL, D. (2007): What are the Determinants of Brownfields Regeneration? An Analysis of Brownfields in England. In: Proceedings of the Conference on the Science and Education of Land Use: A Transatlantic, Multidisciplinary and Comparative Approach, Washington, DC, USA, 24-26 September 2007. Available at: http://nercrd.psu.edu/taluc/ Papers/LongoWhat.pdf.

NICOLE (2011): Environmental Liability Transfer in Europe: Divestment of Contaminated Land for Brownfield Regeneration - Report. Appendix C: Country specific information sheets. [online] Available at: http://www.nicole.org/ documents/DocumentList.aspx?w $=$ bf

NIJKAMP., P., RODENBURG, C. A., WAGTENDONK, A. J. (2002): Success factors for sustainable urban brownfield development: A comparative case study approach to polluted sites. Ecological Economics, Vol. 40, No. 2, p. $235-252$.

OLIVER, L., FERBER, U., GRIMSKI, D., MILLAR, K., NATHANAIL, P. (2005): The scale and nature of European brownfields. In: CABERNET 2005 - International Conference on Managing Urban Land LQM Ltd, Nottingham, UK, Belfast, Northern Ireland, UK. [online] Available at: http://www.cabernet.org.uk/resourcefs/417.pdf. 
PAULL, E. (2008). The Environmental and Economic Impacts of Brownfields Redevelopment. Washington: Northeast-Midwest Institute. [online] Available at: http://www.nemw.org/images/stories/documents/EnvironEconImpactsBFRedev.pdf.

PEDIADITI, K., DOICK, K. J., MOFFAT, A. (2010): Monitoring and evaluation practice for brownfield, regeneration to greenspace initiatives. A meta-evaluation of assessment and monitoring tools. Landscape and Urban Planning, Vol. 97, No. 1, p. 22-36.

PEDIADITI, K., WEHRMEYER, W., CHENOWETH, J. (2005): Monitoring the sustainability of brownfield redevelopment projects: The Redevelopment Assessment Framework. Land Contamination \& Reclamation, Vol. 13, No. 2, p. $173-183$.

PIZZOL, L., CRITTO, A., AGOSTINI, P., MARCOMINI, A. (2011): Regional risk assessment for contaminated sites, Part 2: Ranking of potentially contaminated sites. Environment International, Vol. 37, No. 8, p. 1307-1320.

RALL, L. E., HAASE, D. (2011): Creative Intervention in a Dynamic City: a Sustainability Assessment of an Interim Use Strategy for Brownfields in Leipzig, Germany. Landscape and Urban Planning, Vol. 100, No. 3, p. 189-201.

RRAJM (Regional Development Agency South Moravia) (2010): Brownfields Regeneration in the South Moravian Region (2010): Study created by The Regional Development Agency South Moravia, [online] Available at: http://rrajm. data.quonia.cz/brownfieldy/publikace/2.brownfields_regeneration_in_the_south_moravian_region-case_studies.pdf.

RRAJM (Regional Development Agency South Moravia) (2011): Brownfields regeneration in the South Moravian Region case studies (2011): Regionální rozvojová agentura jižní Moravy, [online] Available at: http://rrajm.data.quonia.cz/brownfieldy/ publikace/2.brownfields_regeneration_in_the_south_moravian_region-case_studies.pdf.

SAYAH, S. M. (2002): Prioritizing Brownfields Redevelopment in the City of Kingston, Ontario. A Report submitted to the School of Urban and Regional Planning. Ontario: Queen's University.

SCHÄDLER, S., MORIO, M., BARTKE, S., ROHR-ZÄNKER, R., FINKEL, M. (2011): Designing sustainable and economically attractive brownfield revitalization options using an integrated assessment model. Journal of Environment Management, Vol. 92, No. 3, p. 827-837.

SCHÄDLER, S., MORIO, M., BARTKE, S., FINKEL, M. (2012): Integrated planning and spatial evaluation of megasite remediation and reuse options, Journal of Contaminant Hydrology, Vol. 124, No. 1-4, p. 88-100.

SILVERTHORNE, T. (2006): What constitutes success in brownfield redevelopment? A review. In: Brebbia, C. A., Mander, U. [eds.], Brownfields III. Prevention, Assessment, Rehabilitation and Development of Brownfield Sites. WIT Press, Southampton, pp. 39-49.

SVOBODOVÁ, H., VĚŽNÍK, A. (2009): To the problems of agricultural brownfields in the Czech Republic, case study of the Vysočina Region. Agricultural Economics, Vol. 55, No. 11, p. 550-556.

SYMS, P. (1994): The funding of developments on derelict and contaminated sites. In. Ball R., Pratt A. C. [eds.]: Industrial Property: political and economic development, London: Routledge, p. 63- 82.

THOMAS, M. R. (2002a): A GIS-based decision support system for brownfield redevelopment. Landscape and Urban Planning, Vol. 58, No. 1, p. 7-23.

THOMAS, M. R. (2002b): A weighted, multi-attribute, site prioritization and selection process for brownfield redevelopment. Environmental Practice, Vol. 4, No. 2, p. 95-106.

TÖLLE, A. (2009): Report about concepts and tools for brownfield redevelopment activities (Output No. 3.1.1 of the COBRAMAN project). Bydgoszcz, Poland. [online] Available at: http://www.central2013.eu/fileadmin/user_upload/ Downloads/outputlib/cobraman_tools_brownfield_regeneration.pdf.

VOJVODÍKOVÁ, B. (2005): Colliery brownfields and the master plan of Ostrava. Moravian Geographical Reports, Vol. 13, No. 2, p. 49-56.

WEDDING, G. C., CRAWFORD-BROWN, D. (2007): Measuring site-level success in brownfield redevelopments: A focus on sustainability and green building. Journal of Environment Management, Vol. 85, No. 2, p. 483-495.

WILLIAMS, K., DAIR, C. (2007): A framework for assessing the sustainability of brownfield developments. Journal of Environmental Planning and Management, Vol. 50, No. 1, p. 23-40.

WONG, C. (1996): What is local economic development? a conceptual overview. Occasional Paper No. 49, Department of Planning and Landscape, University of Manchester.

WONG, C. (1998): Determining factors for local economic development: the perception of practitioners in the North West and Eastern regions of the UK, Regional Studies, Vol. 32, No. 8, p. 707-720.

YOUNT, K. R., MEYER, P. B. (1999): Project scale and private sector environmental decision making: Factors affecting investments in small- and large-scale brownfield projects. Urban Ecosystems, Vol. 3, No. 2, p. 179-193. 


\section{Authors' addresses:}

RNDr. Bohumil FRANTÁL, e-mail: frantal@geonika.cz RNDr. Josef KUNC, Ph.D., e-mail: kunc@econ.muni.cz Mgr. Eva NOVÁKOVÁ, e-mail: novakova@geonika.cz Mgr. Petr KLUSÁČEK, Ph.D., e-mail: klusacek@geonika.cz Mgr. Stanislav MARTINÁT, e-mail: martinat@geonika.cz RNDr. Robert OSMAN, e-mail: osman@geonika.cz Department of Environmental Geography, Institute of Geonics AS CR, v.v.i. Drobného 28, 60200 Brno, Czech Republic

Initial submission 1 April 2013, final acceptance 15 May 2013

Please cite this article as:

FRANTÁL, B., KUNC, J., NOVÁKOVÁ, E., KLUSÁČEK, P., MARTINÁT, S., OSMAN, R. (2013): Location matters! Exploring brownfields regeneration in a spatial context (case study of the South Moravian Region, Czech Republic). Moravian Geographical Reports, Vol. 21, No. 2, p. $5-19$ 